\title{
ШЛЯХИ ПОЛІПШЕННЯ ПОКАЗНИКІВ СПЕРМАТОГЕНЕЗУ В КОМПЛЕКСНОМУ ЛІКУВАННІ ЧОЛОВІЧОГО БЕЗПЛІДДЯ
}

\section{๑А. Д. Беденюк, В. В. Твердохліб, А. І. Мисак, С. О. Нестерук}

Тернопільський національний медичний університет імені І. Я. Горбачевського МОз України

РЕзЮМЕ. В роботі представлені результати дослідження змін показників спермограми у хворих із порушенням сперматогенезу і на фоні лікування харчовою добавкою Ксенодерм. У результаті дослідження виявлено, що препарат Ксенодерм має високу ефективність у лікуванні чоловіків із нетяжкими порушеннями генеративної функції.

Мета - вивчення динаміки змін показників спермограми при лікуванні чоловічого безпліддя препаратом Ксенодерм.

Матеріал і методи. Для оцінки клінічної ефективності та безпечності харчової добавки обстежено 21 пацієнта з хронічним неінфекційним простатитом і порушенням фертильності. В дослідження увійшли чоловіки у віці 2140 років (середній вік 31,4 роки) з діагностованим хронічним простатитом і порушенням фертильності. Тривалість захворювання складала не менше 6 місяців.

Для імунотолеративної корекції структурно-функціональних змін в органах-мішенях використовували таблетований засіб, виготовлений із подрібненого кріоліофілізованого ксенодермального субстрату свині у вигляді харчової добавки Ксенодерм виробництва Інституту біомедичних технологій (м. Тернопіль).

Висновки. Результати дослідження свідчать про високу ефективність препарату Ксенодерм при лікуванні чоловіків із нетяжкими порушеннями генеративної функції, які не зумовлені захворюваннями сечостатевих органів та будь-якими формами гіпогонадизму. Широке використання препарату Ксенодерм слід рекомендувати для поліпшення репродуктивної спроможності пацієнтів із патоспермією граничного і субфертильного рівнів 3 нез'ясованої причини або пов'язаної з нездоровим способом життя. Також може бути доцільним включення препарату Ксенодерм у комплексне лікування чоловіків зі зниженою фертильністю різної етіології.

КлючовІ СлОВА: безпліддя; патоспермія; спермограма.

Вступ. Безпліддя у шлюбі - патологія, значно поширена в світі, зокрема й в Україні. За останніми даними Європейського товариства репродуктології та ембріології людини, в Україні на безпліддя страждає близько 1 млн подружніх пар, тобто 15-17\%. При цьому чоловічий фактор у структурі сімейного безпліддя складає 26,3-49 \% $[1,2]$. Цей показник може бути й вищим, оскільки, як свідчать результати соціологічних опитувань, кількість випадків безпліддя суттєво перевищує число звернень за медичною допомогою з цього приводу.

Безпліддя - це не тільки медико-біологічна, а й соціальна та демографічна проблема. Демографічні показники як в Україні, так і в ряді інших країн світу, свідчать про прогресуюче зниження фертильності серед дорослих чоловіків. В останні десятиріччя декілька разів були переглянуті нормативи спермограми в напрямку значного зменшення числа сперматозоїдів: на сьогодні нормальним вважають наявність більше 20 млн сперматозоїдів в 1 мл еякуляту. Не менш важливою і $\epsilon$ морфологічна характеристика еякуляту. За останні роки було прийнято три державні програми, спрямовані на покращення сексуального і репродуктивного здоров'я населення України.

Порушення фертильності у чоловіків - багатофакторний стан, який може бути пов'язаний як 3 наявністю органічних змін органів статевої системи (варикоцеле, крипторхізм, гіпогонадизм тощо), так і виникати внаслідок дії факторів зовнішнього середовища або мати ідіопатичний характер. Погіршення екологічної рівноваги з кожним роком все більше відображається на репродуктивному здоров'ї людей. Забруднення навколишнього середовища різними хімічними речовинами, нераціональне використання ліків, вплив накопичених рецесивних мутацій створюють фон для розвитку всіх форм безпліддя [3].

Для нормального функціонування статевої системи необхідний фізіологічний рівень концентрації мікроелементів і вітамінів, що беруть участь у біохімічних реакціях і $\epsilon$ каталізаторами цих реакцій. Всім відомо, що багато мікроелементів безпосередньо синтезуються в репродуктивних чоловічих органах. Особливо важливими в цьому аспекті $\epsilon$ іони селену і цинку. На сьогодні відмічається недостатнє забезпечення організму людини необхідними мікроелементами та вітамінами, це $\epsilon$ неабиякою проблемою для цивілізованого суспільства $[4,5]$. Сучасні тенденції такі, що дефіцит вітамінів має характер полігіповітамінозу, супроводжується нестачею мікроелементів і трапляється не тільки взимку і навесні, а й в літньо-осінній період, тобто $\epsilon$ постійно діючим фактором $[6,7]$. 
Огляди літератури, оригінальні дослідження, погляд на проблему, випадок з практики, короткі повідомлення

Труднощі і невдачі в лікуванні чоловічого безпліддя загальновідомі. Як правило, це пов'язано з різноманіттям його причин, механізмів патогенезу і клінічного перебігу. Сучасна класифікація, яка враховує ці фактори $[8,9,10]$, дозволяє диференційовано підходити до комплексного лікування різноманітних форм безпліддя.

Мета - виявити вплив харчової добавки Ксенодерм виробництва Інституту біомедичних технологій (м. Тернопіль) на показники спермограми у хворих з порушенням сперматогенезу.

Матеріал і методи дослідження. у 20152018 рр. на базі урологічного відділення Тернопільської університетської лікарні проведено дослідження з вивчення ефективності і безпечності харчової добавки Ксенодерм при лікуванні хворих з порушенням сперматогенезу. Вивчали вплив Ксенодерму на спермограму, безпечність його оцінювали шляхом аналізу частоти небажаних явищ, побічних ефектів і динаміки клінічних та біохімічних параметрів сироватки крові.

Для оцінки клінічної ефективності й безпечності харчової добавки обстежено 21 пацієнта 3 хронічним неінфекційним простатитом і пору- шенням фертильності. В дослідження увійшли чоловіки у віці 21-40 років (середній вік 31,4 року) 3 доведеним хронічним простатитом і порушенням фертильності. Тривалість захворювання складала не менше 6 місяців.

Дослідження включало збір анамнезу, клінічний огляд, пальцеве ректальне обстеження, оцінку симптомів захворювання за шкалами $\mathrm{NIH}-$ CPSI, IPSS, якість життя - QOL. Усім пацієнтам були виконані клінічні аналізи, мазок секрету простати, ультрасонографія сечового міхура і передміхурової залози з визначенням її об'єму і залишкової сечі. До і після лікування виконували спермограму.

Для імунотолеративної корекції структурнофункціональних змін в органах-мішенях використовували таблетований засіб, виготовлений із подрібненого кріоліофілізованого ксенодермального субстрату свині, у вигляді харчової добавки Ксенодерм виробництва Інституту біомедичних технологій (м. Тернопіль). Вибір вказаного засобу обумовлений широким спектром мікро- і макроелементів, які містяться у кріоліофілізованій ксенодермі (табл. 1).

Таблиця 1. Кількісний склад макро- і мікроелементів у подрібненому кріоліофілізованому ксенодермальному субстраті як основному компоненті харчової добавки Ксенодерм

\begin{tabular}{|l|c|}
\hline \multicolumn{1}{|c|}{ Назва показника } & Вміст, мг/кг \\
\hline Калій (K) & 250 \\
\hline Залізо (Fe) & 600 \\
\hline Титан (Тi) & 90 \\
\hline Кальцій (Сa) & 3300 \\
\hline Свинець (Рb) & $11 / 0$ \\
\hline Хром загальний (Сг) & 30 \\
\hline Кадмій (Cd) & 0,1 \\
\hline Мідь (Сu) & 10 \\
\hline Миш'як (As) & 0 \\
\hline Ртуть (Hg) & 0 \\
\hline Цинк (Zn) & 90 \\
\hline Нікель(Ni) & 15 \\
\hline Барій (Ba) & 3,4 \\
\hline Срібло ( $\mathrm{Ag})$ & 4,0 \\
\hline
\end{tabular}

Наведені в таблиці 1 макро- і мікроелементи важливі для забезпечення ефективного коригувального впливу на патологічні зсуви в організмі на системному рівні, оскільки входять до складу біологічно активних сполук - регуляторів провідних функцій, насамперед органів, тканин і клітин системи імунного захисту. Те саме стосується широкого за спектральним складом вмісту амінокислот (табл. 2), поліфункціональна роль яких в оптимізації розбалансованого окисно-відновного гомеостазу та забезпеченні нормальної регенерації тканин загальновідома. Важливим також $\epsilon$ вміст у субстраті ксеношкіри епідермального фактора росту .

Результати й обговорення. Встановлено, що до початку лікування у 86,0 \% пацієнтів була патоспермія граничного рівня, у 14,0 \% - субфертильного. Виражених або критичних (азооспермія 
Огляди літератури, оригінальні дослідження, погляд на проблему, випадок з практики, короткі повідомлення

Таблиця 2. Кількісний склад амінокислот у подрібненому кріоліофілізованому ксенодермальному субстраті основному компоненті харчової добавки Ксенодерм

\begin{tabular}{|l|c|c|}
\hline \multicolumn{1}{|c|}{ Показники, мг/100г } & Результати визначення & Похибка визначення \\
\hline Аргінін & 901,53 & $\pm 0,35$ \\
\hline Лізин & 1224,72 & $\pm 0,35$ \\
\hline Аланін & 1473,54 & $\pm 0,35$ \\
\hline Треонін & 1436,65 & $\pm 0,35$ \\
\hline Гліцин & 2632,65 & $\pm 0,35$ \\
\hline Валін & 678,95 & $\pm 0,35$ \\
\hline Серин & 1843,76 & $\pm 0,35$ \\
\hline Пролін & 3447,44 & $\pm 0,35$ \\
\hline Ізолейцин & 522,72 & $\pm 0,35$ \\
\hline Лейцин & 1489,12 & $\pm 0,35$ \\
\hline Гістидин & 498,17 & $\pm 0,35$ \\
\hline Фенілаланін & 1086,31 & $\pm 0,35$ \\
\hline Глутамінова кислота & 2291,18 & $\pm 0,35$ \\
\hline Аспарагінова кислота & 1581,44 & $\pm 0,35$ \\
\hline Тирозин & 1004,11 & $\pm 0,35$ \\
\hline
\end{tabular}

та аспермія) відхилень у показниках спермограм в обстежених чоловіків виявлено не було. Здебільшого спостерігали зміни якісних параметрів еякуляту, що мали ізольований або поєднаний характер: астенозооспермія була у 66,0 \% чоловіків, астенотератозооспермія - у 24,0 \%, тератозооспермія - у 10 \%. Зниження концентрації сперматозоїдів нижче за 20 млн/мл виявлено у 14,0% обстежених. Але цей показник не був меншим за 15 млн/мл, тобто олігозооспермія в усіх пацієнтів була невираженою. В усіх чоловіків зниження кількісних показників еякуляту поєднувалося 3 якісними: олігоастенозооспермія була у 10,0 \% осіб, олігоастенотератозооспермія - у 4,0%. Дослідження сперми в чоловіків після трьох місяців монотерапії препаратом Ксенодерм показало, що в 80,0 \% пацієнтів показники еякуляту покращилися: збільшилися рухливість сперматозоїдів, їх концентрація, зменшилася кількість дегенеративних форм. Найчутливішим до проведеної терапії виявився показник рухливості сперматозоїдів: астенозооспермія, як ізольована, так і в поєднанні з іншими видами патоспермії, знизилася з 92,0 \% до 28,0 \%. У 20,0 \% осіб раніше визна- чені параметри сперми залишилися на попередньому рівні. Погіршення показників еякуляту в жодного з обстежених не виявлено. Внаслідок лікування у 62,0 \% чоловіків вдалося досягти стану нормозооспермії; у 38,0 \% пацієнтів патоспермія лишилася або досягла граничного рівня. Випадків порушень репродуктивного потенціалу субфертильного рівня задокументовано не було. Всі обстежені добре переносили терапію препаратом Ксенодерм.

Висновки. Проведені дослідження свідчать про високу ефективність препарату Ксенодерм у лікуванні чоловіків із нетяжкими порушеннями генеративної функції, які не зумовлені захворюваннями сечостатевих органів та будь-якими формами гіпогонадизму. Широке використання препарату Ксенодерм слід рекомендувати для покращення репродуктивної спроможності пацієнтів із патоспермією граничного і субфертильного рівня неясної причини або пов'язаної з нездоровим способом життя. Також включення препарату Ксенодерм може бути доцільним при комплексному лікуванні чоловіків зі зниженою фертильністю різної етіології.

\section{ЛІТЕРАТУРА}

1. Горпинченко И. И. Анализ гендерных проблем при супружеском бесплодии / И. И. Горпинченко, О. В. Романенко, К. Р. Нуриманов // Здоровье мужчин. 2004. - № 1. - C. 14-16.

2. Дедов И. И. Возрастной андрогенный дефицит у мужчин / И. И. Дедов, С. Ю. Калинченко. - М., 2006. -239.

3. Костєв Ф. І. Особливості патогенезу вторинної чоловічої неплідності / И. И. Дедов, С.Ю.Калинченко // Урологія. - 2004. - № 2. - С. 72-76.

4. Сивков А. В. Эффективность и безопасность препарата Селцинк Плюс у пациентов с хроническим неинфекционным простатитом и нарушениями фер- 
Огляди літератури, оригінальні дослідження, погляд на проблему, випадок з практики, короткі повідомлення тильности / А. В. Сивков, В. Н. Ощепков, В. В. Евдокимов // Экспериментальная и клиническая урология. 2010. - № 1. - C. 49-54.

5. The importance of folate, zinc and antioxidants in the pathogenesis and prevention of subfertility / I. M. Ebisch, C. M. Thomas, W. H. Peters [et al.] // Hum Reprod Update. - 2007. - No. 13 (2). - P. 163-174.

6. Safarinejad M. R. Efficacy of selenium and/or N-acetylcysteine for improving semen parameters in infertile men: a double-blind, placebo controlled, randomized study / M. R. Safarinejad, S. Safarinejad // J. Urol. - 2009. No. 181 (2). - P. 741-751.

\title{
REFERENCES
}

1. Gorpinchenko, I.I., Romanenko, O.V., \& Nurimanov, K.R. (2004). Analiz gendernykh problem pri supruzheskom besplodii [Analysis of gender problems in marital infertility]. Zdorovye muzhchin - Men's Health, 1, 14-16 [in Russian].

2. Dedov, I.I., \& Kalinchenko, S.Yu. (2006). Vozrastnoy androgennyy defitsit u muzhchin [Age androgen deficiency in men]. Moscow [in Russian].

3. Kostiev, F.I., \& Chystiakov, R.B. (2004). Osoblyvosti patohenezu vtorynnoi cholovichoi neplidnosti [Peculiarities of the pathogenesis of secondary male infertility]. Urolohiia - Urology, 2, 72-76 [in Ukrainian].

4. Sivkov, A.V., Oshchepkov, V.N., \& Yevdokimov, V.V. (2010). Effektivnost i bezopasnost preparata Seltsink Plyus $u$ patsiyentov s khronicheskim neinfektsionnym prostatitom i narusheniyami fertilnosti [The efficacy and safety of Selzink Plus in patients with chronic non-infectious prostatitis and fertility disorders]. Eksperimentalnaya $i$ klinicheskaya urologiya - Experimental and Clinical Urology, 1, 49-54 [in Russian].

5. Ebisch, I.M., Thomas, C.M., Peters, W.H., Braat, D.D., \& Steegers-Theunissen R.P. (2007). The importance of fo-

late, zinc and antioxidants in the pathogenesis and prevention of subfertility. Hum. Reprod. Update, 13 (2), 163174.

6. Safarinejad, M.R., \& Safarinejad, S. (2009). Efficacy of selenium and/or $\mathrm{N}$-acetylcysteine for improving semen parameters in infertile men: a double-blind, placebo controlled, randomized study. J. Urol., 181 (2), 741-751.

7. Skalnyy, A. V. (2004). Khimicheskiye elementy $v$ fiziologii i ekologii cheloveka [Chemical elements in human physiology and ecology]. Moscow: izdatelskiy dom "ONIKS 21 vek": Mir [in Russian].

8. Nikitin, O. D. (2009). Besplodnyy brak v Ukraine: perspektivy i tendentsii [Afetal marriage in Ukraine: prospects and trends]. Zdorovye muzhchiny - Men's Health, 4, 211-215 [in Russian].

9. Sapsay, V.I., Imshenitskaya, L.P., \& Sapsay, V.V. (2005). Muzhskoye besplodiye [Male infertility]. Kyiv: "Avrora plyus" [in Russian].

10. Barret-Connor, E., Goodman-Gruen, D., \& Patay, B. (1999). Endogenous sex hormones and cognitive in older men. J. Clin. Endocrinol. Metab., 84, 3681-3686

\section{ПУТИ УЛУЧШЕНИЯ ПОКАЗАТЕЛЕЙ СПЕРМАТОГЕНЕЗА В КОМПЛЕКСНОМ ЛЕЧЕНИИ МУЖСКОГО БЕСПЛОДИЯ}

\author{
๑А. Д. Беденюк, В. В. Твердохлиб, А. И. Мысак, С. А. Нестерук
}

Тернопольский национальный медицинский университет имени И. Я. Горбачевского Моз Украины

PЕЗЮМЕ. В работе представлены результаты исследования изменений показателей спермограммы у больных с нарушением сперматогенеза и на фоне лечения пищевой добавкой Ксенодерм. В результате исследования выявлено, что препарат Ксенодерм имеет высокую эффективность в лечении мужчин с нетяжелыми нарушениями генеративной функции.

Цель - изучение динамики изменений показателей спермограммы при лечении мужского бесплодия препаратом Ксенодерм.

Материал и методы. Для оценки клинической эффективности и безопасности пищевой добавки обследован 21 пациент с хроническим неинфекционным простатитом и нарушением фертильности. В исследование вошли мужчины в возрасте 21-40 лет (средний возраст 31,4 года) с диагностированным хроническим простатитом и нарушением фертильности. Длительность заболевания составляла не менее 6 месяцев.

Для иммунотолеративной коррекции структурно-функциональных изменений в органах-мишенях использовано таблетированное средство, изготовленное из измельченного криолиофилизованого ксенодермального 
Огляди літератури, оригінальні дослідження, погляд на проблему, випадок з практики, короткі повідомлення субстрата свиньи, в виде пищевой добавки Ксенодерм производства Института биомедицинских технологий (г. Тернополь).

Выводы. Результаты исследования свидетельствуют о высокой эффективности препарата Ксенодерм при лечении мужчин с нетяжелыми нарушениями генеративной функции, не обусловленными заболеваниями мочеполовых органов и любыми формами гипогонадизма. Широкое использование препарата Ксенодерм следует рекомендовать для улучшения репродуктивной состоятельности пациентов с патоспермией предельного и субфертильного уровней, обусловленной невыясненной причиной или связанной с нездоровым образом жизни. Также может быть целесообразным включение препарата Ксенодерм в комплексное лечение мужчин со сниженной фертильностью различной этиологии.

КЛючЕВЫЕ СЛОВА: бесплодие; патоспермия; спермограмма.

\title{
WAYS TO IMPROVE INDICATORS OF SPERMATOGENESIS IN COMPLEX TREATMENT OF MALE INFERTILITY
}

\author{
@A. D. Badenyuk, V. V. Tverdokhlib, A. I. Mysak, S. O. Nesteruk \\ I. Horbachevsky Ternopil National Medical University
}

SUMMARY. The paper presents the results of a study of changes in sperm indices in patients with impaired spermatogenesis and against the background of treatment with the food additive Xenoderm. As a result of the study, it was revealed that the drug Xenoderm has a high efficacy in the treatment of men with mild violations of the generative function.

The aim - to study the dynamics of changes in semen indices in the treatment of male infertility with Xenoderm.

Material and Methods. To assess the clinical efficacy and safety of a food additive, 21 patients with chronic noninfectious prostatitis and fertility disorders were examined. The study included men aged 21-40 years (mean age 31.4 years) diagnosed with chronic prostatitis and impaired fertility. The disease duration was at least 6 months.

For immunotolerative correction of structural and functional changes in target organs, a tabletting agent was used, made from crushed cryo-lyophilized xenodermal pig substrate, in the form of a food additive Xenoderm produced by the Institute of Biomedical Technologies (Ternopil).

Conclusions. The results of the study indicate the high efficacy of the drug Xenoderm in the treatment of men with mild violations of the generative function, not caused by diseases of the urogenital organs and any form of hypogonadism. Extensive use of the drug Xenoderm should be recommended to improve the reproductive viability of patients with patospermia of marginal and subfertile levels, due to an unexplained cause or associated with an unhealthy lifestyle. It may also be advisable to include the drug Xenoderm in the complex treatment of men with reduced fertility of various etiologies.

KEY WORDS: infertility; pathospermia; spermogram.

Отримано 12.04.2019 